\title{
Reformasi hukum keluarga di dunia Muslim
}

\author{
Ahmad Bunyan Wahib \\ Jurusan al-Ahwal Asy-Syakbsiyyah \\ Fakultas Syariah UIN Sunan Kalijaga Yogyakarta \\ Email:ahmadbunyanwabib@gmail.com
}

This article discusses about the history and the development of family law reform in Muslim countries. This work has taken a lot benefits from Anderson's works on Islamic law in the Muslim world for both data and perspective. Islamic family law reform started from the second decade of twentieth century (1915) with the issuance of two Ottoman Caliph decrees on wife rights to ask religious court to divorce them from their husband. This reform was followed by Sudan (starting from 1916), Egypt (1920), Jordan (1951), Syria (1953), Tunisia (1956/1959), Morocco (1958), Iraq (1959), Pakistan (1961) and Iran (1967). The reformation aims to administrate the members of community in the filed of social, economy, politics, and law. From the perspective of modernization, Islamic family law reform in Muslim countries has shown the process of modernization from above.

Artikel ini membahas tentang perkembangan reformasi hukum keluarga di negara-negara Muslim. Dari segi sumber data dan pespektif teoretis, tulisan ini banyak memanfaatkan data dan teori yang dipaparkan dalam karya-karya J.N.D. Anderson tentang pembaharuan hukum Islam di dunia Islam. Pembaharuan hukum keluarga secara resmi telah dimulai semenjak awal abad keduapuluh (1915) dengan keluarnya dekrit Khalifah Turki Usmani tentang hak isteri. Setelah itu menyusul beberapa Negara lain seperti Sudan (mulai 1916), Mesir (1920), Jordania (1951), Syiria (1953), Tunisia (1956/1959), Maroko (1958), Irak (1959), dan Pakistan (1961), Iran dengan tradisi Syiahnya (1967). Dalam konteks perkembangan modernisasi dan modernitas, reformasi hukum keluarga Islam yang terjadi di dunia Muslim adalah bentuk modernisasi dari atas. Inisiatif reformasi hukum Islam biasanya berasal dari pemerintah dengan tujuan untuk mengatur masyarakat dengan beberapa alasan, seperti alasan ekonomi, politik, sosiologis dan alasan hukum.

Keywords: Islamic family law reform; Modernization from above; Muslim countries; Government 
ljtihad, Jurnal Wacana Hukum Islam dan Kemanusiaan, Volume 14, No. 1, Juni 2014: 1-19

\section{Pendahuluan}

Dalam kajian akademik mengenai hukum Islam, sebagian sarjana (Barat) berpendapat bahwa hukum Islam merupakan salah satu elemen paling penting dalam ajaran Islam (Humphreys, 1991: 209). Pengaruh hukum Islam masuk ke dalam bidang-bidang lain dalam studi keislaman. Dalam bahasa Schacht, hukum Islam menjadi simbol pemikiran Islam, dan menjadi manifestasi cara hidup Islam yang paling khas dan jelas: "Islamic law is the epitome of Islamic thought, the most typical manifestation of the Islamic way of life, the core and kernel of Islam itself" (Schacht, 1964: 1). Komentar serupa juga disampaikan oleh Gibb dalam Mohammedanism. Dalam bahasa Gibb, syariah (hukum Islam) merepresentasikan pengetahuan paling penting (master science) dan agen yang paling efektif dalam membentuk tatanan sosial dan kehidupan komunitas umat Islam. Hukum Islam telah melahirkan kekuatan sosial Islam melalui pasang surut yang terjadi dalam sejarah perkembangan politik di dunia Islam (Gibb, 1962: 9-11).

Pengaruh hukum Islam yang demikian kuat dalam kehidupan umat Islam juga dapat dilihat dari kuatnya perspektif hukum yang mempengaruhi cara pandang umat Islam dalam melihat problem kehidupan keseharian. Sifat hukum Islam yang tidak hanya berdimensi eksoteris hukum, tetapi juga mengandung unsure moral menjadikannya berpengaruh luas dalam membentuk cara pandang umat Islam (Rahman, 1979: 67). Antara hukum dan moral saling berkelindan, dan dalam banyak hal tidak mungkin dipisahkan. Dari sinilah status hukum dalam Islam tidak hanya berupa batasan hitam putih seperti halal dan haram saja, tetapi juga ada varian-varian lain seperti sunnah (sebaiknya dilakukan) dan mubah (dilakukan atau dihindari) dan makruh (sebaiknya dihindari).

Dengan peranannya yang sangat penting seperti di atas, hukum Islam dalam berbagai aspeknya, mulai dari hukum bisnis (mu'ämalab), pidana (j̈nāyah) dan perdata (al-aḥwäl alShakhsiyyah) menjadi sistem hukum yang sangat vital dan pernah menjadi satu-satunya rujukan yang tidak tertandingi di dunia Islam (Anderson, 1971: 1-21). Dunia Islam sangat konsisten untuk menggunakan sistem hukum agama ini dalam perundang-undangan mereka dalam waktu yang lama. Namun demikian, dunia Islam tidak dapat mengelakkan dari perubahan hukum. Negara-negara Muslim telah melakukan berbagai pembaharuan hukum dengan alasan sosiologis, yaitu masyarakat memerlukan perubahan (Anderson, 1965: 355). Sedangkan dari segi pemerintahan, salah satu alasan utamanya adalah efisiensi birokrasi hukum dalam 
tata negara bangsa. Tuntutan ini telah memaksa negara-negara Muslim untuk memodifikasi aturan hukum materiil dan melengkapi prosedur administrasi peradilan negara modern dengan melahirkan hukum acara Islam (Anderson, 1975: 10-33). Tulisan ini membahas tentang perkembangan pembaharuan hukum keluarga di negara-negara Muslim. Pembahasan mencakup sejarah reformasi, asal-usul gagasan reformasi, dan alasan-alasan utama reformasi hukum keluarga.

\section{Reformasi hukum Turki Usmani}

Dalam sejarah perkembangan hukum Islam, secara umum, imunitas hukum Islam dari elemen asing bertahan hingga pertengahan abad ke sembilan belas. Selama itu, hukum Islam menjadi satu-satunya rujukan dalam berbagai aspek kehidupan bernegara di dunia Islam. Tetapi kondisi ini mulai berubah mulai pertengahan abad kesembilanbelas (tahun 1850). Sistem hukum Barat menjadi salah satu sistem hukum yang berpengaruh penting terhadap perubahan yang terjadi dalam hukum Islam. Pembaharuan ini dimulai oleh Kekaisaran Turki Usmani. Ketika itu, Turki Usmani membentuk lembaga Tanzimat, sebuah lembaga reformasi, yang diberi mandat untuk melakukan reformasi (sekularisasi) kenegaraan (Lane dkk., 2009: 132), termasuk reformasi dalam bidang hukum. Reformasi ini dimulai awal dekade 1840an.

Reformasi hukum di Turki ditandai dengan reformasi hukum pidana pada tahun 1840 (Lane dkk., 2009: 132). Reformasi hukum pidana ini diteruskan pada tahun 1858 (Anderson, 1971: 2). Turki juga mereformasi hukum dagang tahun 1841(Lane dkk., 2009: 132), dan tahun 1850 (Anderson, 1971: 2). Reformasi hukum dagang ini diteruskan dengan dibuatnya Kitab Acara Hukum Dagang tahun 1861 dan tahun 1863 disusul oleh Kitab undang undang Perdagangan maritim (Anderson, 1971: 2). Reformasi hukum pidana dan hukum dagang ini juga dapat disebut sebagai sekularisasi. Dari segi materi hukum, semua kitab undang-undang baru tersebut merujuk kepada sistem hukum Barat (Perancis/Napoleon Code) dan ditangani oleh sistem peradilan sekular (Anderson, 1971: 2).

Salah satu warisan monumental dari reformasi hukum Turki adalah munculnya kodifikasi hukum al-Majallat al-Ạ̣kām al-Adliyyah atau al-Majallah tahun 1870 (1869-1876). Al-Majallah ini menjadi kode sipil (kitab hukum perdata) di seluruh wilayah kekaisaran Turki Usmani dan dianggap sebagai Kode Sipil pertama dunia Islam. Sumber hukum materi al-Majallah 
secara mayoritas diambil dari pandangan mazhab Hanafi. Di Turki al-Majallah diganti secara total dengan Kitab Hukum Perdata Swiss pada tahun 1926 (Lane dkk., 2009: 132), sebagai salah satu efek dari sekularisasi yang dijalankan oleh pemerintahan Turki modern di bawah pimpinan Kemal. Meskipun peranan al-Majallah di Turki telah berakhir tahun 1926, akan tetapi al-majallah masih tetap bertahan cukup lama di wilayah lain yang pernah menjadi wilayah kekaisaran Turki Usmani sehingga terjadi reformasi hukum baru seperti Libanon (1932), Syria (1949) dan Iraq (1953). Malahan, meskipun telah terjadi reformasi hukum, materi yang ada dalam al-majallab Turki tetap menjadi sumber materi hukum penting dalam hukum baru tersebut.

Reformasi (sekularisasi) hukum yang terjadi di Turki berpengaruh terhadap sistem peradilan, yaitu terjadinya dikotomi dalam peradilan dan perundang-undangan (hukum). Dalam bidang peradilan muncul dua sistem peradilan, yaitu peradilan sekular dan peradilan agama. Peradilan sekular lahir sebagai pengaruh langsung dari sekularisasi dalam reformasi hukum yang dijalankan. Turki mengadopsi sistem peradilan Barat untuk mengatur dan menerapkan hukum substantif (materi hukum) dengan cara menerapkan perundangundangan (legislative enactments) modern, menerapkan dan menjalankan hukum acara modern, dan diisi oleh orang-orang hukum (hakim dan ahli hukum) yang terdidik dalam lembaga sekolah modern. Sedangkan peradilan agama menangani hukum keluarga dengan meneruskan tradisi hukum yang didominasi mazhab Hanafi, menerapkan prosedur peradilan warisan klasik dengan hakim dan ahli hukum yang terdidik secara tradisional (Anderson, 1971: 3).

Dalam bidang hukum, dikotomi mewujud dengan munculnya dua sistem hukum, yaitu: pertama, hukum yang terkodifikasi dalam kitab undang-undang, dan sebagian besar merupakan hukum Eropa; kedua, hukum tradisional yang tidak terkodifikasi yang berlaku dan dipraktekkan dalam masyarakat. Dari kedua sistem hukum ini, hukum keluarga merupakan bagian dari hukum yang tidak terkodifikasi. Dalam perkembangan awal ini, pembaruan/reformasi hukum tidak menyentuh hukum keluarga. Hukum keluarga tetap menggunakan sistem hukum lama dan dengan substansi hukum yang diambil dari Mazhab Hanafi (Anderson, 1971: 2).

Setelah reformasi di Turki, reformasi hukum di dunia Islam juga terjadi di Mesir (Lane dkk., 2009: 132). Pembaharuan yang diserukan oleh reformis dari Mesir seperti Muhammad 
Abduh dan Qasim Amin ikut memberi pengaruh pada bidang hukum. Dari segi perjalanan reformasi hukum, sejatinya reformasi hukum di Mesir hampir bersamaan dengan pembaharuan hukum di Turki. Mesir melepaskan diri dari pengaruh hukum al-Majallah Daulah usmaniyah pada tahun 1873/1874, tidak lama setelah diundangkan di Turki pada awal tahun 1870 (Anderson, 1971: 3). Tahun 1875 terjadi reformasi hukum di Mesir dengan dibentuk dan diterapkannya peradilan sipil untuk peradilan campuran (mixed court/al-mabkamah al-mukbtallah) dan peradilan negeri (national court/al-mablkamah al-abliyyah). Kedua sistem peradilan ini dilengkapi hukum yang sebagian besar mengadopsi sistem hukum Perancis (kitab undang-undang napoleon (Code Napoleon) dan sebagian lagi diambil dari hukum Islam. Hukum yang lahir meliputi hukum pidana, hukum dagang dan hukum maritim. Setelah itu menyusul hukum kepemilikan (1891) dan hukum wakaf (1893).

Meskipun telah terjadi pembaruan di berbagai bidang hukum, perubahan hukum yang terjadi di Mesir tidak menyentuh bidang hukum keluarga. Hukum keluarga tetap merujuk kepada hukum tradisional yang telah berlaku dalam masyarakat (mazhab Hanafi). Dengan demikian, sampai akir abad ke sembilan belas tidak pernah terjadi pembaruan hukum keluarga di dunia Islam. Satu produk hukum yang dekat dengan hukum keluarga adalah hukum wakaf tahun 1893. Meskipun telah lahir hukum wakaf, tetapi hanya terbatas pada administrasi hukum, sedangkan materi hukum tidak ada yang berubah (Lane dkk., 2009: 133).

Reformasi hukum yang terjadi di Mesir mempunyai pengaruh yang sama dengan reformasi hukum Turki. Pasca reformasi hukum ini muncul dikotomi sistem peradilan, yaitu peradilan umum dan peradilan syariah. Mesir membentuk peradilan syariah untuk menangani masalah hukum keluarga dalam pengertiannya yang luas (mencakup waris, wasiat, wakaf, dan perkawinan) dengan materi hukum yang berasal dari tradisi hukum Islam yang didominasi hukum mazhab Hanafi (Lane dkk., 2009: 133).

Pembaruan hukum Islam seperti di Mesir juga diikuti oleh Tunisia. Tunisia melakukan perubahan hukum pada masa yang hampir bersamaan dengan Mesir. Lagi-lagi, pembaruan hukum Islam di Tunisia juga tidak menyentuh hukum keluarga. Pada tahun 1874 Tunisia mengeluarkan peraturan tentang wakaf, wakaf diatur secara terpusat. Akan tetapi aturan baru ini tidak dapat dijalankan dengan serta merta. Ketentuan mengenai wakaf ini baru dapat dijalankan setelah Tunisia merdeka tahun 1956 (Lane dkk., 2009: 134). Dengan 
ljtihad, Jurnal Wacana Hukum Islam dan Kemanusiaan, Volume 14, No. 1, Juni 2014: 1-19

demikian, hingga akhir abad kesembilan belas, belum ada reformasi hukum keluarga di negara-negara Islam. Hukum keluarga Islam masih imun terhadap pengaruh kemodernan.

\section{Sejarah pembaharuan hukum keluarga Islam}

Reformasi hukum keluarga baru terjadi pada perengahan dasawarsa kedua abad ke duapuluh, tepatnya tahun 1915. Sekali lagi, reformasi hukum keluarga ini dimulai dari Turki. Turki Usmani menjadi negara pertama yang melakukan reformasi hukum keluarga dengan keluarnya dua keputusan Khalifah Dinasti Usmaniyah (two imperial decrees), Sultan Muhammad V, mengenai hak para isteri. Dinasti Usmaniyah yang banyak mengadopsi aturan hukum dari mazhab Hanafi harus mengamandemen perundang-undangan mengenai hak-hak isteri. Amandemen ini dilakukan karena Mazhab Hanafi dirasa tidak memberi hak yang adil terhadap fihak isteri. Menurut mazhab Hanafi, seorang isteri yang ditinggal oleh suaminya selama bertahun-tahun, atau suaminya mengidap penyakit yang membahayakan perkawinan, tidak mempunyai hak untuk mengajukan cerai. Ketentuan mazhab Hanafi ini memaksa Sultan untuk ikut campur tangan dalam bidang hukum dengan keluarnya dua dekrit Raja.

Dekrit pertama mengatur tentang hak isteri yang ditinggal pergi oleh suaminya. Untuk ketentuan mengenai masalah ini, dekrit raja memberikan hak kepada isteri untuk mengajukan cerai dengan mengikuti pendapat mazhab Maliki dan Hanbali, bukan lagi mazhab Hanafi. Dekrit yang kedua memberikan hak kepada isteri untuk mengajukan cerai jika suaminya terbukti sakit lepra atau sakit jiwa. Hak ini diberikan kepada isteri jika sebelum menikah ia tidak mengetahui jika calon suaminya tersebut menderita sakit lepra atau sakit jiwa. Pendapat ini sesuai dengan pendapat dominan mazhab ortodoksi selain Mazhab Hanafi, dan juga pendapat lemah dari mazhab Hanafi. Dengan keluarnya dua dekrit raja tersebut, Mazhab Hanafi, yang menjadi rujukan utama Daulah Usmaniyah ditinggalkan dan berpindah kepada mazhab ortodoks sunni lain yang lebih memihak kepada isteri (Anderson, 1965: 352).

Dua tahun setelah dua dekrit raja diundangkan, pada tahun 1917 Kerajaan Turki Usmani mengundangkan undang-undang hukum keluarga. Berbeda dengan al-Majallah yang hanya mengadopsi mazhab Hanafi, undang-undang hukum keluarga ini menjadi sebuah bentuk amalgamasi hukum. Meskipun undang-undang ini masih menjadikan mazhab Hanafi sebagai prioritas rujukan, tetapi telah memberikan ruang yang lebih luas untuk berbagai pandangan 
yang ada dalam mazhab-mazhab sunni ortodoks yang lain. Materi hukum dalam undangundang keluarga ini merujuk kepada berbagai pandangan yang ada dalam mazhab Hanafi dan pandangan dominan dari mazhab Maliki, Syafi’i dan Hanbali. Akan tetapi, hukum keluarga ini tidak bertahan lama. Negara Turki Baru (Republik Turki) yang dideklarasikan tahun 1923 kemudian melakukan sekularisasi pemerintahan, termasuk dalam bidang hukum dan peradilan. Tahun 1924, satu tahun setelah deklarasi Turki modern, sistem peradilan agama dihapuskan. Tahun 1927 Turki juga mengganti hukum keluarga dengan mengadopsi Kitab UndangUndang Hukum Perdata Swiss. Dalam bidang hukum keluarga ini, Turki Modern melakukan sekularisasi total. Sistem hukum baru ini secara formal sama sekali tidak merujuk kepada aturan syariah (Welchman, 2007: 12-13). Ini sekaligus menghentikan proses pembaharuan hukum keluarga Islam di Turki modern.

Setelah reformasi pertama Turki Usmani tahun 1915, reformasi hukum keluarga juga terjadi di Sudan dengan langkah hakim Agung pada masa itu mengeluarkan Judicial Circular No. 17 Tahun 1916 (Anderson, 1978: 312), sebuah perubahan hukum mengenai nafkah dan pemeliharaan isteri oleh suami dengan memperkenalkan mazhab Hanafi dalam masyarakat Sudan. Hakim agung ini mengeluarkan 57 surat edaran yang mengikat Pengadilan Syariah berkaitan dengan berbagai persoalan dalam hukum keluarga dalam pandangan mazhab Hanafi, pendapat yang tidak populer di kalangan masyarakat Sudan yang menganut mazhab Maliki (Akolawin, 1973: 155). Reformasi hukum keluarga ini terus berkelanjutan sehingga tahun 1940an dengan dikeluarkannya banyak Edaran Hukum yang berkaitan dengan hukum keluarga (Anderson, 1978: 317-320).

Kembali kepada reformasi hukum keluarga Turki, pembaharuan hukum keluarga Turki Usmani tahun 1915 dan 1917 dan sekularisasi hukum yang dilakukan oleh Turki modern banyak memberi pengaruh terhadap perkembangan hukum keluarga di dunia Islam. Meskipun undang-undang hukum keluarga Islam Turki Usmani diberlakukan hanya sekitar satu dasawarsa, tetapi berbagai kajian yang mencoba mengkaji kontinuitas penerapan hukum keluarga Islam (Hukum Keluarga Turki Usmani) pada negara-negara bekas wilayah Turki usmani menunjukkan adanya pengaruh hukum ini di negara-negara tersebut. Hukum keluarga Syria, Jordan (Anderson, 1965: 353; Anderson, 1971: 6), dan Palestina (Welchman, 2007: 12), banyak mengadopsi hukum keluarga Turki Usmani. Di tempat lain seperti Lebanon 
dan Israel, materi undang-undang Turki ini diberlakukan dengan penyesuaian dan dimodifikasi (Anderson, 1965: 352; Anderson, 1971: 5-6; Welchman, 2007: 13). Selain itu, proses sekularisasi hukum yang dilakukan oleh Turki dengan Tanzimatnya dan pendirian Turki Modern juga telah memberi inspirasi bagi negara-negara di dunia Islam untuk melakukan sekularisasi dalam bidang hukum, meskipun bukan sekularisasi penuh (Anderson, 1965: 352).

Setelah Turki Usmani, kodifikasi dan pembaruan hukum keluarga terjadi di Mesir pada tahun 1920. Ini ditandai dengan diundangkannya UU No 25/1920 mengenai hukum keluarga dan penjagaan (Law of Maintenance and Personal Status/ Qanün al-Ahwäl al-Shakbsiyyah wa alsiyanab). Reformasi hukum di Mesir ini terus terjadi secara berkelanjutan sehingga awal tahun 1950an. Lembaga hukum di Mesir secara bertahap melakukan reformasi hukum yang berpengaruh penting terhadap hukum keluarga (perkawinan dan waris). UU no 25 Tahun 1920 ini kemudian diikuti oleh undang-undang lain seperti UU No. 56/1923 mengenai batasan usia perkawinan, UU no. 25/1929 mengenai aturan perceraian dan pertengkaran dalam rumah tangga ((Lane dkk., 2009: 133), disusul oleh kitab undang-undang sipil/perdata (civil code) tahun 1931, UU no. 77/1943 mengenai hukum waris, dan UU no 71/1946 mengenai hukum wasiat. Setelah itu, kurun waktu 1960an sampai 1970an, berbagai peristiwa politik juga ikut menentukan terjadinya reformasi hukum keluarga. Reformasi hukum keluarga pada tahun 1970an ditandai dengan dikeluarkannya aturan undang-undang mengenai kewenangan kepada lembaga peradilan memaksa fihak-fihak (suami) untuk membayar uang pemeliharaan kepada isteri-isteri, janda-janda, anak-anak, ataupun orang tua pada tahun 1976.

Pada tahun 1979, setelah gagal mendapatkan persetujuan untuk mengeluarkan undangundang hukum keluarga, Anwar Sadat secara sepihak mengeluarkan dekrit darurat yang diundangkan menjadi UU no 44/1979. Undang-undang ini dikenal dengan undang-undang Jihan (Jehan's Law atau Jiji's Law), karena diusulkan oleh Jehan Sadat atau Jiji Sadat, Isteri Anwar Sadat (An-Na'im, 2002: 169). Undang-undang ini banyak merevisi undang undang hukum keluarga mesir yang dihasilkan pada tahun 1920 dan 1929, terutama mengenai peranan dan hak perempuan dalam keluarga.

Akan tetapi, pada bulan Mei 1985, UU no 44/1979 ini digugat dengan diajukannya judicial review ke Mahkamah Tinggi Konstitusi (High Constitutional Court). Judicial review diajukan 
untuk menilai status undang-undang Jehan ini. Hasilnya, Mahkamah konsitiusi Mesir menyatakan bahwa undang-undang tersebut bertentangan (ultra vires) dengan Konstitusi Mesir. Mahkamah menolak status dekrit darurat undang-undang ini dengan beralasan dekrit darurat yang dikeluarkan oleh Presiden Anwar Sadat untuk memberlakukan UU no 44 tahun 1979 sesungguhnya dikeluarkan dalam keadaan tidak darurat. Oleh karena itu dekrit tersebut harus dianggap tidak valid.

Beberapa bulan setelah pembatalan undang-undang Jehan, pemerintah Mesir mengundangkan UU no. 100/1985, sebuah amandemen hukum untuk merevisi hukum keluarga tahun 1920 dan 1929. Sejumlah perubahan yang sebelumnya telah diundangkan dalam UU tahun 1979 diundangkan kembali dalam undang-undang tahun 1985 ditambahkan dengan beberapa aturan baru. Tahun 2005, Mesir mengeluarkan UU no 4/2005 yang isinya mengamandemen Dekrit Hukum No 25 Tahun 1920 (yang mengubah umur perwalian).

Dari segi substansi hukum, amandemen tahun 2005 menunjukkan kembalinya Mesir dengan undang-undang konservatif. Salah satunya adalah dicabutnya hak otomatis dari isteri untuk bercerai dengan suaminya jika suaminya melakukan poligami. Pasal yang menyatakan sakit atau cedera yang dialami oleh isteri disebabkan oleh suami yang berpoligami sebagai syarat isteri mengajukan cerai dihilangkan dari perundang-undangan. Sebagai gantinya, syarat bercerai mengharuskan isteri untuk menyatakan bahwa dia merasa tersiksa karena suami berpoligami (kembali kepada pendapat klasik). Aturan ini merupakan konsensus pemerintah Mesir dengan para tokoh agama konservatif sekaligus dengan kalangan Muslim liberal.

Selain ketiga Negara ini, beberapa negara Islam yang lain juga telah melakukan reformasi hukum keluarga. Jordania mereformasi undang-undang Usmaniah tahun 1951, dan Syiria tahun 1953. Tunisia mereformasi hukum keluarga (Code of Personal Status) tahun 1956 (dengan tambahan appendix tahun 1959), kemudian menyusul Maroko tahun 1958, Irak tahun 1959 (amandemen tahun 1963), dan Pakistan tahun 1961. Sedangkan Iran dengan tradisi Syiahnya melakukan reformasi hukum pada tahun 1967 (Family Protection Act). Setelah itu, Uni Emirat Arab juga melakukan reformasi hukum pada akhir tahun 2005 dan Qatar tahun 2006 (Welchman, 2007: 13). 
ljtihad, Jurnal Wacana Hukum Islam dan Kemanusiaan, Volume 14, No. 1, Juni 2014: 1-19

\section{Metode reformasi hukum keluarga}

Reformasi hukum mencakup hukum prosedural/acara dan hukum material atau substansi hukum. Reformasi hukum formal berkaitan dengan pembaharuan terhadap prosedur hukum (hukum acara) dengan cara mengadopsi hukum acara Barat. Jenis reformasi ini melahirkan administrasi hukum Islam (Anderson, 1975: 13). Aturan syariah muncul dalam wajah undangundang modern yang lebih sistematis. Selain itu, diberlakukan pula aturan administratif dalam hukum syariah seperti pencatatan pernikahan dalam hukum keluarga (Anderson, 1975: 13), dan klaim perceraian dengan pembuktian dokumen (Anderson, 1976: 45). Reformasi prosedural ini dijustifikasi dengan konsep takhsis al-qadä, hak penguasa untuk mengatur dan menentukan jurisdiksi lembaga peradilan, yang memang dikenal dalam peradilan Islam (Anderson, 1976: 45).

Reformasi substansi hukum dilakukan dengan cara takhayyur (pemilihan pendapat hukum), talfīq (amalgamasi mazhab hukum), dan ijtihäd (inovasi/penemuan hukum). Takhayyur dilakukan dengan mengadopsi ketentuan dari pendapat hukum yang ada yang dinilai sesuai dengan masyarakat. Talf̄iq dilakukan dengan cara eklektik, dengan mengkombinasikan beberapa pendapat hukum yang ada sehingga didapatkan ketentuan hukum yang sesuai dengan masyarakat. Ijtihäd dilakukan dengan cara melakukan interpretasi ulang terhadap teks-teks keagamaan. Ijtihad dilakukan jika tidak takhayyur dan talfiq tidak bisa dilakukan (Anderson, 1971: 7-12).

Penerapan metode takhayyur dapat dilihat dalam reformasi hukum keluarga Islam awal yang berupa dua dekrit Sultan Turki tahun 1915 mengenai hak isteri. Dekrit sultan yang memilih pendapat dari mazhab non Hanafi daripada pendapat dominan dalam mazhab Hanafi telah menandai perubahan hukum dalam sistem hukum yang didominasi mazhab Hanafi. Selanjutnya, metode ini banyak digunakan dalam Hukum Keluarga Turki Usmani seperti akad nikah yang memilih Mazhab Syafi'i (pasal 36), larangan menikahkan anak bawah umur yang lebih dekat kepada pendapat Syi'ah (pasal 9) (Anderson, 1976: 48-49). Cara seperti ini juga ditemukan di Sudan dan Mesir. Reformasi hukum Sudan yang terdapat dalam edaran-edaran hukum mengenalkan mazhab Hanafi dalam masyarakat yang menganut mazhab Maliki. 
Di negara-negara Muslim Sunni, metode takhayyur ini bisa dilakukan dengan beberapa alternatif. Pertama, meninggalkan aturan yang ada dan mencari pendapat alternatif yang ada dalam satu tradisi mazhab yang sama. Ini dilakukan dengan meninggalkan pendapat dominan dan beralih kepada pendapat yang tidak populer dalam satu mazhab. Kedua, Jika cara pertama tidak dapat dilakukan, takhayyur dilanjutkan dengan mencari pandangan yang berkembang dan populer dalam mazhab sunni (ortodoks). Ketiga, jika cara kedua tidak dapat dilakukan, maka dilanjutkan dengan mencari pendapat dari mazhab sunni yang tidak populer. Keempat, jika tidak menemukan pendapat seperti dalam cara ketiga, maka pencarian hukum dilanjutkan dengan melihat pendapat fuqahä' khalaf. Kelima, jika semua cara tersebut tidak dapat dilakukan, maka pencarian hukum dilakukan dengan mengadopsi aturan hukum yang berkembang dalam tradisi Syi'ah (Anderson, 1976: 51).

Metode talfï dilakukan dengan menggabungkan beberapa pendapat dalam satu ketentuan. Ini dapat dilihat dalam Edaran hukum Sudan No. 49 Tahun 1939 mengenai bagian waris untuk saudara/saudari kandung atau seibu jika bersama dengan kakek dari garis ayah. Surat edaran ini lebih memilih untuk memberikan hak waris kepada saudara/ saudari tersebut bersama dengan kakek dengan mengadopsi pendapat Abu Yusuf, al-Syaibani dan ulama Syafi'iyah dan malikiyah sesuai dengan prinsip Zaid bin Tsabit. Contoh talfiq yang lain mengenai aturan waris Muslim dan non Muslim di Mesir. Muslim tidak mewarisi dari non Muslim dan sebaliknya. Tetapi non Muslim boleh saling mewarisi. Sedangkan perbedaan negara tidak menjadi penghalang untuk mewarisi, kecuali jika negara (asing) tersebut membuat peraturan demikian. Aturan ini merupakan penggabungan beberapa pendapat yang berkembang di kalangan sunni (Ibid., 1976: 48-49). Demikian juga aturan mengenai radd untuk pasangan (suami/isteri) dalam aturan hukum Tunisia tahun 1956.

Selain takhayyur dan talfiq , cara terakhir adalah dengan menafsirkan kembali teks-teks keagamaan (ijtiha $\bar{d})$. Penafsiran ulang ini telah banyak digunakan untuk memaknai kembali doktrin-doktrin hukum (keluarga) Islam dalam semua aspeknya. Hukum perkawinan dan perceraian telah menjadi lahan yang subur bagi terjadinya penafsiran kembali teks-teks keagamaan ini. Dalam konteks ini, poligami menjadi salah satu isu penting dari permulaan reformasi hukum keluarga. Isu ini dimulai pada tahun 1898 ketika Muhammad Abduh menulis artikel dalam sebuah surat kabar yang menggugat pemahaman tradisional tentang 
syarat-syarat poligami. Isu ini kemudian digaungkan dengan publikasi sebuah buku Tabrir al-Mar'ah (pembebasan perempuan) oleh Qasim Amin pada tahun 1900. Isu ini kemudian mempengaruhi hukum keluarga Turki Usmani tahun 1917. Meskipun pada akhirnya gagaan Abduh dan Qasim Amin tidak masuk dalam undang-undang keluarga tahun 1929 karena adanya penolakan dari Raja Fu'ad, tetapi pemikiran Abduh dan Qasim Amin menjadi perbincangan seirus di kalangan komite reformasi hukum di Mesir yang dibentuk tahun 1926. Dalam konteks perkembangan reformasi hukum di dunia Islam, ide-ide progresif Abduh dan Qasim Amin tentang poligami menjadi inspirasi bagi reformasi di negara-negara Muslim lain seperti Syria, Irak, Tunisia, Maroko dan yang lain (Anderson, 1976: 61-64).

Selain dengan tiga metode tersebut di atas, terdapat pula reformasi hukum melalui putusan/penetapan pengadilan. Reformasi dengan putusan/penetapan pengadilan ini terjadi di negara-negara Muslim bekas kolonial Inggris dan terpengaruh oleh sistem hukum Inggris seperti negara-negara di anak benua India seperti Pakistan, India dan Bangladesh. Di negaranegara ini, pertemuan antara hukum Islam dengan sistem hukum Inggris telah menghasilkan sistem hukum Anglo-Islam (Anglo-Muhammadan Law). Di bawah sistem hukum ini, hukum Islam diterapkan oleh para hakim dan dengan hukum acara dalam sistem hukum Inggris. Dalam negara dengan tradisi Anglo-Islam ini, proses pembaharuan hukum dilakukan dengan melakukan revisi terhadap putusan pengadilan yang telah ada dengan putusan baru (yurisprudensi hukum), sebuah sistem yang dijalankan dalam tradisi hukum Anglo Saxon (Anderson, 1976: 77-81).

Reformasi hukum di dunia Islam dengan berbagai metode seperti di atas pada intinya adalah melakukan revisi (meninjau) ulang terhadap ketentuan hukum agama (syariah) agar dapat menjawab kebutuhan hukum dalam masyarakat. Dalam beberapa hal, perubahan hukum Islam ini dapat dikatakan sebagai adaptasi syariah (the adaptation of the shari'a) terhadap perubahan yang terjadi dalam masyarakat (Anderson, 1971: 5). Adaptasi syariah ini dilakukan dengan cara penyesuaian syariah terhadap perkembangan masyarakat sehingga hukum Islam kompatibel dengan masyarakat modern. Oleh karena itu, tidak jarang dalam membuat ketentuan hukum baru tersebut harus mengorbankan aturan hukum lama yang sudah dipraktekkan. Reformasi hukum dalam bentuk adaptasi syariah ini bisa berwujud modifikasi ketentuan lama atau mengganti ketentuan lama dengan ketentuan baru (Coulson, 1969: 145). 
Setidaknya terdapat tiga elemen yang berpengaruh terhadap reformasi hukum di dunia Islam, yaitu: sistem hukum Barat (modern), mazhab hukum Islam, dan tradisi lokal (Coulson, 1969: 149-202). Ketiga unsur ini berpengaruh penting terhadap pembaruan hukum yang terjadi di dunia Islam dari segi hukum formil maupun materiil. Dari pertemuan ketiga unsur hukum tersebut, setidaknya sistem hukum di dunia Islam mewujud dalam tiga kelompok. Pertama negara yang tetap menjadikan syariah sebagai rujukan hukum; kedua, negara yang telah menggantikan syariah dengan hukum sekuler (Barat); ketiga, negara yang menggabungkan syariah dan hukum sekuler (Anderson, 1959: 83).

Dari ketiga sistem hukum tersebut, mayoritas negara-negara Islam menerapkan jenis ketiga dengan mengkombinasikan syariah dan hukum sekuler dalam reformasi hukumnya. Hanya sedikit yang mengambil langkah ekstrim dengan menitikberatkan pada salah satu dari ketiga unsur tersebut. Arab Saudi menjadi negara yang dapat dikategorikan dalam kelompok pertama. Negara ini menjadikan syariah sebagai rujukan dalam hukum (Anderson, 1959: 83-86) meskipun sebenarnya dalam bidang (kasus) tertentu, mu'amalah, negara ini juga telah meninggalkan syariah. Dalam bidang pajak, Arab Saudi telah melakukan amalgamasi hukum dengan membuat regulasi pajak penghasilan yang memadukan hukum syariah dengan sistem pajak Amerika (Anderson, 1959: 85). Sedangkan Turki menjadi negara yang mengambil langkah bertolak belakang dari Arab Saudi dengan sekularisasi hukum yang ekstrem dengan meninggalkan syariah dan mengadopsi hukum Barat. Akan tetapi, dalam praktiknya, masih banyak masyarakat yang masih menggunakan hukum keluarga Islam (Anderson, 1959: 87-89).

\section{Mengapa reformasi hukum?}

Reformasi hukum berhubungan erat dengan bagaimana negara/pemerintah mengatur rakyat/masyarakat secara efektif dan efisien. Anderson mencatat bahwa dukungan terhadap reformasi hukum di dunia Islam, tidak hanya dalam hukum keluarga, disebabkan oleh beberapa alasan seperti alasan ekonomi, politik, hukum dan sosial. Alasan ekonomi sangat jelas terlihat dalam perubahan hukum dagang yang berkaitan dengan hukum yang mengatur aktivitas ekonomi (Anderson, 1971: 15). Dalam konteks reformasi hukum keluarga, reformasi mengenai peraturan wakaf dapat dijadikan contoh. Wakaf mempunyai potensi yang sangat 
besar sebagai alat untuk mengumpulkan aset kekayaan nasional. Oleh karena itu harus ada aturan yang dapat mengoptimalkan peranan wakaf ini. Selain wakaf, perbankan juga penting untuk mendukung pertumbuhan ekonomi. Bagi kelompok reformis, pemahaman tradisional terhadap aturan yang ada dalam syariah tentang bunga dan perbankan terlalu kaku dan ketat. Bunga bukanlah sistem transfer kekayaan yang dibenarkan oleh syariah. Jika pemahaman ini dibiarkan dan diterapkan dalam masyarakat, maka beragam jenis kontrak finansial yang bersifat spekulatif akan jatuh ke tangan orang-orang asing (Anderson, 1971: 3).

Selain alasan ekonomi, sebagian lain karena alasan politis. Alasan ini sangat erat kaitannya dengan kepentingan dunia Islam mensikapi gagasan dari luar (gagasan asing). Dalam konteks ini, kepedulian umat Islam untuk mengikuti langkah progresif yang telah dilakukan Barat meniscayakan terjadinya perubahan. Perubahan ini sekaligus untuk membuktikan kepada fihak luar (Barat) mengenai kemampuan dunia Islam membebaskan diri dari sistem hukum (Islam) yang dinilai sudah tidak tepat untuk diterapkan dalam masyarakat modern seperti hukuman rajam bagi pezina dan hukuman potong tangan bagi pencuri (Anderson, 1971: 3). Dalam konteks hukum keluarga, menilai usia kehamilan selama dua, empat atau bahkan lima tahun menjadi aturan yang dapat dikatakan usang. Perkembangan pengetahuan dan takhnologi dunia medis telah mampu memprediksi usia kehamilan untuk menentukan status anak dalam kandungan dapat ditentukan dengan perkiraan yang akurat. Oleh karena itu, pembaharuan hukum menjadi sebuah keniscayaan.

Alasan lainnya adalah alasan hukum, yaitu perlunya aturan hukum (legislasi hukum) yang sesuai dengan sistem hukum modern. Kepentingan ini tidak hanya berimplikasi kepada prosedur dan administrasi hukum, tetapi juga terhadap substansi hukum. Contohnya adalah bukti tertulis untuk kasus hukum tertentu. Kesaksian lisan tidak memadai untuk kasus hukum yang memerlukan bukti yang terperinci.

Sedangkan dari segi sosial, alasan ini merujuk kepada arti pentingnya hukum bagi masyarakat. Hukum yang baik harus dapat menjawab persoalan yang ada dalam masyarakat, bukan berfungsi sebagai pengendali layaknya baju pengekang yang selalu menghalangi perkembangan dan kemajuan dalam masyarakat. Oleh karena itu, reformasi hukum penting untuk dilakukan (Anderson, 1971: 4). 
Reformasi hukum keluarga di dunia Muslim (Ahmad Bunyan Wahib)

\section{Reformasi hukum Islam, bentuk modernisasi dari atas}

Modernisasi mengindikasikan adanya transformasi masyarakat dalam bentuk perubahan mendasar yang terjadi secara terus menerus, dan ini memerlukan kesiapan dan kemampuan masyarakat untuk menjalankannya (Bill, 1970: 19). Barrington Moore menyebutkan tiga cara yang dilakukan negara dalam proses modernitas, yaitu kapitalisme bebas (laissez-faire capitalism), kapitalisme negara (state capitalism), dan komunis (communist). Kapitalisme bebas merupakan gabungan antara kapitalisme dan demokrasi parlementer. Ini terbentuk setelah terjadi rangkaian panjang revolusi seperti yang terjadi pada revolusi Perancis dan Perang saudara di Amerika. Kapitalisme negara terbentuk oleh kapitalisme minus revolusi. Ini terjadi melalui bentuk-bentuk politik reaksioner dalam sistem politik yang fasis (Moore, 1966: 413).

Reformasi kapitalisme negara disebut juga reformasi dari atas. Ini biasa terjadi dalam negara yang kuat (otoritarian). Negara jenis ini bisanya ditandai dengan pemerintahan yang sangat sentralistik dan peranan negara yang dominan (Lane dkk, 2009: 168). Dalam situasi seperti ini, negara mempunyai kebebasan untuk membuat kebijakan, termasuk melakukan reformasi dan modernisasi. Untuk mendukung reformasi, biasanya negara/pemerintah menjalin kerjasama dengan kelompok aristokrat dan kelompok elit lainnya untuk merubah tatanan tradisional dan kemudian melakukan modernisasi.

Dari beberapa perspektif di atas, reformasi hukum Islam yang terjadi di dunia Arab secara umum masuk dalam kategori modernisasi dengan jalan state capitalism. Inisiatif atau gagasan awal dalam proses reformasi hukum Islam yang terjadi di dunia Arab datang dari pemerintah untuk kepentingan rasionalisasi dan efisiensi hukum (Anderson, 1971: 3-4; Ibid., 1976: 14-15; Lane dkk., 2009: 127-144). Diawali dari keinginan pemerintah akan perlunya sistem hukum yang rasional dan lebih kompatibel dengan kehidupan masyarakat, negaranegara Muslim mulai melakukan reformasi hukum dengan berbagai varian alasan. Alasan utama adalah efisiensi administrasi hukum, sikap terhadap pendapat dan pengaruh asing (Barat/Modern) (Anderson, 1971: 1-21), dan juga tradisi lokal untuk membentuk aturan baru yang kompatibel dengan bebagai alasan, seperti alasan hukum, ekonomi, politik dan sosiologis (Ibid., 3-4). Untuk efisiensi administrasi hukum dan efektifitas penerapan hukum, dan juga penerimaan terhadap pengaruh dan ide asing, dunia Islam melakukan reformasi 
hukum prosedural dan hukum material. Tidak jarang reformasi hukum ini harus meninggalkan tradisi hukum yang telah lama diamalkan.

Reformasi hukum di Turki yang berakhir dengan sekularisasi penuh menunjukkan bagaimana kehendak pemerintah melakukan perubahan hukum telah meninggalkan tradisi hukum yang ada. Dimulai dari pembentukan tanzimat menjelang tahun 1840an untuk melakukan modernisasi pemerintahan sehingga keputusan Turki untuk mengganti hukum sipilnya dengan hukum Swedia menunjukkan bahwa inisiatif modernisasi hukum dari negara. Inisiatif dari atas seperti Turki ini menjadi model reformasi hukum di negara-negara Islam yang lain di kawasan Timur Tengah dan Afrika seperti Mesir, Tunisia, Jordania, Iraq, Maroko, Sudan, anak benua India, dan Asia Tenggara, termasuk Indonesia.

Dalam proses reformasi hukum di dunia Islam, biasanya negara/kaum birokrat berhadapan dengan kalangan tradisional dengan tokoh (ulama)nya yang masih setia mengamalkan tatanan tradisional. Dalam menghadapi kelompok ini, pemerintah mendapat dukungan dari kelompok masyarakat yang terdidik dalam lingkungan pendidikan modern. Kelompok ini adalah masyarakat urban yang terdidik dalam sistem pendidikan modern, dan merupakan kalangan masyarakat yang telah akrab dengan kemodernan yang menjadi dasar dari gagasan-gagasan yang digunakan sebagai bahan reformasi hukum. Keakraban masyarakat urban dengan kemodernan ini telah menjadikan kelompok masyarakat ini dengan cepat mendukung pembaharuan hukum negara (Lane, dkk., 2009: 127).

Reformasi hukum dari atas yang terjadi di dunia Islam, termasuk reformasi hukum, cukup berhasil karena pemerintahan dunia Arab (Islam) pada masa proses reformasi hukum ini berlangsung sangat kuat bahkan cenderung autoritarian (Lane, dkk., 2009: 127). Mayoritas negara-negara Islam melakukan reformasi hukum tidak lama setelah merdeka, dengan peranan militer yang cukup dominan. Dalam negara yang kuat dan cenderung otoriter seperti ini, tidak ada kekuatan rakyat yang dapat menghalangi kehendak negara membuat kebijakan, meskipun terkadang tidak sesuai dengan kehendak mayoritas masyarakat (Lane, dkk., 2009: 127).

Namun demikian, tidak selamanya reformasi hukum Islam di dunia Islam berhasil dilakukan. Keputusan Turki Modern untuk melakukan sekularisasi penuh dengan mengadopsi hukum keluarga Swiss pada tahun 1927 dapat menjadi contoh "kegagalan" reformasi hukum 
Islam yang dijalankan. Syariah tidak lagi menjadi rujukan hukum. Bertele-telenya pembahasan mengenai rancangan undang-undang hukum keluarga Islam menjadi sebab dibatalkannya reformasi hukum Islam di negara ini (Welchman, 2007: 12-13). Selain itu, beberapa negara Islam juga gagal untuk mempertahankan reformasi hukum yang telah dijalankan. Apa yang terjadi dengan Undang-Undang Jehan (Jehan's Law) tahun 1979 di Mesir dapat menjadi contoh yang sangat baik. Undang-undang Jehan ini dikeluarkan ketika Pemerintahan Anwar Sadat sangat kuat. Para pengamat menyatakan bahwa Undang-Undang lahir ketika parlemen tidak ada pilihan lain untuk menyetujui draft yang diajukan pemerintah. Pada tahun 1985, empat tahun setelah Anwar Sadat terbunuh, Mahkamah Tinggi Konstitusi Mesir membatalkan undang-undang Jehan karena tidak konstitusional. Undang-undang Jehan direvisi dengan Undang-undang No. 100 tahun 1985. Revisi yang paling penting adalah revisi hak cerai secara otomatis bagi isteri yang dipoligami. Hak otomatis isteri untuk bercerai diganti dengan hak bercerai setelah diputuskan oleh pengadilan. Isi amandemen tersebut merupakan kompromi dari kalangan Muslim konservatif dan kelompok liberal (el-Alami, 1994: 116).

Kasus serupa juga terjadi di Irak. Hasil proses reformasi hukum keluarga Irak yang cukup panjang telah menghasilkan sebuah kitab hukum keluarga yang diklaim telah mengakomodir dua hukum yang banyak dipraktekkan dalam masyarakat (Hanafi/Sunni dan Itsna 'Asyari/Syi'ah). Aturan hukum ini menjelma menjadi kitab hukum keluarga tahun 1958. Akan tetapi hanya bertahan kurang dari lima tahun (1963), tidak lama setelah terjadi kudeta. Arah kebijakan negara dalam bidang sosial politik berpengaruh penting dalam proses reformasi hukum di negara-negara Islam ini. Terdapat persamaan sebab terjadinya revisi undang-undang keluarga di Mesir dan Irak, yaitu pergantian pemerintahan, kudeta di Iraq dan pembunuhan Anwar Sadat di Mesir; ketidakpuasan masyarakat terhadap hasil reformasi hukum. Pengadopsian aturan baru dinilai terlalu radikal dan tidak sesuai dengan aturan hukum syariah. Oleh karena itu, ketika terjadi pergantian kekuasaan, terjadi perubahan aturan hukum keluarga (Anderson, 1963: 1027).

\section{Simpulan}

Perkembangan hukum di dunia Islam telah menunjukkan fleksibilitas hukum keluarga Islam dengan adanya reformasi hukum keluarga di negara-negara Muslim. Dalam konteks ini, 
reformasi hukum keluarga merupakan hasil dari dinamika internal hukum Islam dan dialog antara hukum Islam dengan sistem hukum Barat dan adat. Hukum Islam dengan khazanah inelektual dan variasi mazhabnya telah menghasilkan produk hukum dengan cara takhayyur (pemilihan alternatif hukum), talfiq (amalgamasi hukum). Sedangkan dialog antara hukum Islam dengan dua sistem hukum yang lain, selain telah menghasilkan amalgamasi hukum, juga telah menghasilkan inovasi/penemuan hukum (ijtihad).

Dari perspektif modrnisasi, reformasi hukum di dunia Islam merupakan salah satu bentuk reformasi dari atas. Inisiatif perubahan hukum di negara-negara Islam berasal dari pemerintah/negara. Berangkat dari keinginan negara untuk mengatur masyarakat Islam dengan tetap berasaskan hukum Islam, negara-negara Islam melakukan reformasi hukum dengan berbagai alasan seperti alasan ekonomi, politik, sosiologi, atau alasan hukum sendiri. Dalam perjalanannya, beberapa hasil usaha reformasi hukum harus dibatalkan karena tidak mendapatkan dukungan yang kuat masyarakat. Tumbangnya penguasa penggagas reformasi dan ketidaksesuaian reformasi dengan tuntutan masyarakat menjadi sebagian sebab penting dihentikannya reformasi hukum Islam.

Secara teoretis, pembatalan produk reformasi hukum yang terjadi di dunia Islam berkaitan dengan pengadopsian hukum asing dalam masyarakat. Dalam konteks penerapan hukum, reformasi hukum dari atas yang terjadi di negara-negara Muslim dapat dikatakan sebagai adopsi dan implementasi hukum asing (dari luar) kepada masyarakat Muslim. Dalam konteks globalisasi, dalam usaha untuk melakukan rekayasa sosial (social engineering) melalui hukum, pengadopsian pemerintah/negara terhadap hukum asing sebagai salah satu rujukan untuk membuat aturan hukum sepetinya tidak dapat dielakkan. Globalisasi telah menjadikan dunia sebagai wilayah tanpa sempadan. Dalam konteks ini, diperlukan kearifan dan kecerdasan dalam proses pengadopsian tersebut karena tidak semua hukum asing dapat diterima oleh masyarakat. Mengutip Robert Seidman, terdapat hukum yang tidak bisa dipaksakan (nontransferability of law) kepada masyarakat. Oleh karena itu, usaha rekayasa sosial melalui reformasi hukum dari atas harus mempertimbangkan tradisi hukum (legal culture) yang ada dalam masyarakat yang merepresentasikan perlunya hukum dan makna penting hukum dalam masyarakat. Dengan begitu, buah reformasi hukum dapat diterapkan dalam masyarakat dan tidak perlu dianulir. 
Reformasi hukum keluarga di dunia Muslim (Ahmad Bunyan Wahib)

\section{Daftar pustaka}

Akolawin, Natale Olwak, "Personal Law in the Sudan-Trends and Developments", Journal of African Law, Vol. 17, No. 2 (Summer, 1973): 149-195.

Anderson, J.N.D. Islamic Law in Africa. London: Frank Cass, 1978.

Anderson, Norman. Law Reform in the Muslim World. London: University of London/The Athlone Press, 1976.

Anderson, J.N.D., "Modern Trends in Islam: Legal Reform and Modernization in the Middle East", The International and Comparative Law Quarterly, Vol. 20. No. 1 (Januari, 1971): 121.

Anderson, J.N.D., "Recent Reforms in Islamic Law of Inheritance", The International and Comparative Law Quarterly, Vol. 14, No. 2 (April, 1965): 349-365.

Anderson, J.N.D., "Changes in the Islamic Law of Personal Status in Iraq", The International and Comparative Law Quarterly, Vol. 12, No. 3 (Juli, 1963): 1026-1031.

Anderson, J.N.D. Islamic Law in the Modern World. Ttp.: New York University Press, 1959.

An-Na'im, Abdullahi Ahmed. Islamic Family Law in a Changing World: A Global Resource Book. 2002.

Bill, James A., "Modernization and Reform from Above: the Case of Iran", Journal of Politics, Vol. 32, No. 1 (Februari, 1970): 19-40.

Coulson, Noel J. History of Islamic Law. Edinburg: Edinburg University Press, 1999.

Gibb, H.A.R. Mohammedanism. New York: Galaxy Book/Oxford University Press, 1962.

Humphreys, Stephen R. History of Islam. New Jersey: Princeton University Press, 1991.

Lane, Jan-Erik, Hamadi Redissi, Riyad Saydawi. Religion and Politics: Islam and Muslim Civilization. Farnham/Burlington: Ashgate Publishing Company, 2009.

Moore Jr., Barrington. Social Origins of Dictatorship and Democracy. Boston: Beacon Press, 1966.

Rahman, Fazlur. Islam. Chicago: University of Chicago Press, 1979.

Schacht, Joseph. an Introduction of Islamic Law. Oxford: Clarendon Press, 1964.

Welchman, Lynn. Women and Muslim Family Laws in Arab States: A Comparative Overview of Textual Development and Advocacy. Amsterdam: ISIM/Amsterdam University Press, 2007. 